\title{
Effect of the Side Cutting-Edge Angle on the Surface Roughness for Aluminum 1350 in the Turning Operation by Taguchi Method
}

\author{
L.Rico*$^{* 1}$, S. Noriega*2 ${ }^{* 2}$ J.L.García ${ }^{3}$, E.A.Martínez ${ }^{4}$, R. Ñeco ${ }^{5}$, F.J.Estrada ${ }^{6}$ \\ 1,2,3,4,5,6 Universidad Autónoma de Ciudad Juárez \\ Department of Industrial and Manufacturing Engineering \\ Avenida del Charro 450 C.P. 32310 \\ Col. Partido Romero \\ Ciudad Juárez Chih. \\ Tel:656 6884843 \\ *larico@uacj.mx
}

\begin{abstract}
The purpose of this work was to analyze the effect of the side cutting-edge angle on the surface roughness of aluminum 1350 in a turning operation. A Taguchi design L32 was used in this work; the control variables were spindle speed, feed rate, depth of cutting and the side cutting-edge angle. Several metal cutting experiments and statistical tests provide evidence that the side cutting-edge angle significantly affects the surface roughness with a Statistical $F$ equal to 24.96, mainly, when the side cutting-edge angle is maintained at high level; in this study, the high level was kept to 5.0 degrees. Also, when the high level condition is kept, it causes a major variation of the residual values; consequently, the surface roughness of the workpiece falls out of the specifications demanded by customers. Moreover, the best combination of the cutting parameters for a minimum surface roughness equal to $23.5 \mu$ in was obtained. Finally, further research directions are presented.
\end{abstract}

Keywords: Side cutting-edge angle, Taguchi method, surface roughness

\section{RESUMEN}

El propósito de este trabajo fue analizar el efecto del ángulo de corte de la herramienta sobre la rugosidad superficial del aluminio 1350 en la operación de torneado. Se uso un diseño Taguchi L32 en este trabajo; las variables de control fueron velocidad del husillo, tasa de alimentación, profundidad de corte y el ángulo de corte de la herramienta. Los experimentos y pruebas estadísticas realizadas mostraron que con una $\mathrm{F}$ estadística igual a 24.96, el ángulo de la herramienta de corte afecta significativamente la rugosidad superficial, principalmente, cuando el ángulo de corte se mantiene a un nivel alto; en este estudio, el nivel se mantuvo a 5 grados. Además, cuando esta condición se mantiene, causa una mayor variación en los residuales; consecuentemente, la textura de la pieza de trabajo cae fuera de la especificación demandada por el cliente. Adicionalmente, se obtuvo la mejor combinación de los parámetros de corte para una mínima rugosidad superficial igual a $23.5 \mu \mathrm{in}$. Finalmente, se hacen algunas recomendaciones para futuras investigaciones.

\section{Introduction}

Surface roughness is a performance indicator of the machining processes that has received great attention during the last year. It is sometimes a design feature as important as fatigue loads, precision fits and aesthetic requirements [1]. A mathematical model traditionally used in the text books is given in Equation 1:

$$
R_{i}=\frac{f^{2}}{32 r}
$$

This model explains how the feed rate $f$ and the nose radii of the cutting tool $r$ affect the surface roughness $\mathbf{R} \mathbf{i}$. However, it is important to consider other factors that, according to experts, significantly affect the surface roughness. A considerable quantity of investigations have been done considering other cutting parameters such as cutting speed, feed rate, depth of cutting and cutting tool geometry. Table 1 shows some works found in the literature. 


\begin{tabular}{|c|c|c|c|}
\hline Author & Control Parameters & $\begin{array}{l}\text { Significant } \\
\text { Parameters }\end{array}$ & Operation \\
\hline [2] Nalbant et al. & $\begin{array}{l}\text { Feed rate, depth of cut } \\
\text { and cutting tool } \\
\text { geometry }\end{array}$ & $\begin{array}{l}\text { Feed rate and cutting } \\
\text { tool nose }\end{array}$ & Turning \\
\hline [3] Zhang et al. & $\begin{array}{l}\text { Spindle speed, feed } \\
\text { rate and cutting speed, } \\
\text { Noise factors: } \\
\text { Temperature and } \\
\text { cutting tool wear }\end{array}$ & $\begin{array}{l}\text { Spindle speed, feed } \\
\text { rate and cutting tool } \\
\text { wear }\end{array}$ & Milling \\
\hline [4] Mohamed et al. & $\begin{array}{l}\text { Cutting speed, feed } \\
\text { rate and depth of cut }\end{array}$ & $\begin{array}{l}\text { Feed rate and depth of } \\
\text { cut }\end{array}$ & Turning \\
\hline [5] Ghani et al. & $\begin{array}{l}\text { Cutting speed, feed } \\
\text { rate and depth of cut }\end{array}$ & $\begin{array}{l}\text { Cutting speed, feed } \\
\text { rate and depth of cut }\end{array}$ & Milling \\
\hline [6] Puertas et al. & $\begin{array}{l}\text { Cutting speed, feed } \\
\text { rate and depth of cut }\end{array}$ & $\begin{array}{l}\text { Feed rate and depth of } \\
\text { cut }\end{array}$ & Turning \\
\hline $\begin{array}{l}\text { [7] P. G. Benardos \& } \\
\text { G.C. Vaniakos }\end{array}$ & $\begin{array}{l}\text { Cutting speed, feed } \\
\text { rate, depth of cut, } \\
\text { forces, cutting tool } \\
\text { Wear and Cutting Fluid }\end{array}$ & $\begin{array}{l}\text { Feed rate, forces, depth } \\
\text { of cut and cutting fluid }\end{array}$ & Milling \\
\hline [8] Darwish & $\begin{array}{l}\text { Workpiece hardness, } \\
\text { feed rate and depth of } \\
\text { cut }\end{array}$ & $\begin{array}{l}\text { Feed rate and depth of } \\
\text { cut }\end{array}$ & Turning \\
\hline [9] Beauchamp et al. & $\begin{array}{l}\text { Cutting speed, feed } \\
\text { rate, depth of cut, radii } \\
\text { of the cutting tool nose, } \\
\text { long of the cutting tool } \\
\text { and long of the work } \\
\text { piece }\end{array}$ & $\begin{array}{l}\text { Feed rate, radii of the } \\
\text { cutting tool nose and } \\
\text { interaction between } \\
\text { feed rate and cutting } \\
\text { speed. }\end{array}$ & Turning \\
\hline [10] Alauddin et al. & $\begin{array}{l}\text { Cutting speed, feed } \\
\text { rate and depth of cut }\end{array}$ & $\begin{array}{l}\text { Cutting speed and feed } \\
\text { rate }\end{array}$ & Milling \\
\hline
\end{tabular}

Table 1. Parameters of the numerical example 
Table 1 shows some works related with the study of cutting parameters such as cutting speed, feed rate, depth of cut, cutting tool geometry and other variables on the surface roughness. However, the effect of the side cutting-edge angle on the surface roughness has not been considered widely by experts and according to machinist, when the square turret is rotated to one side cutting-edge angle, the imperfect nose geometry of the cutting tool affects the roughness surface when it touches the workpiece. On the other hand, Kalpakjian [11] claims that the side cutting-edge angle affects chip formation, tool strength, and cutting forces. Nevertheless, it is important to mention that the side cutting-edge angle can significantly affect the surface roughness mainly when the workpiece is machined in a conventional lathe using a high side cutting-edge angle. Figure 1 outlines the main parts of a conventional lathe. On the other hand, Figure 2 shows the parts of the cutting tool and the location of the side cutting-edge angle in the turning operation.

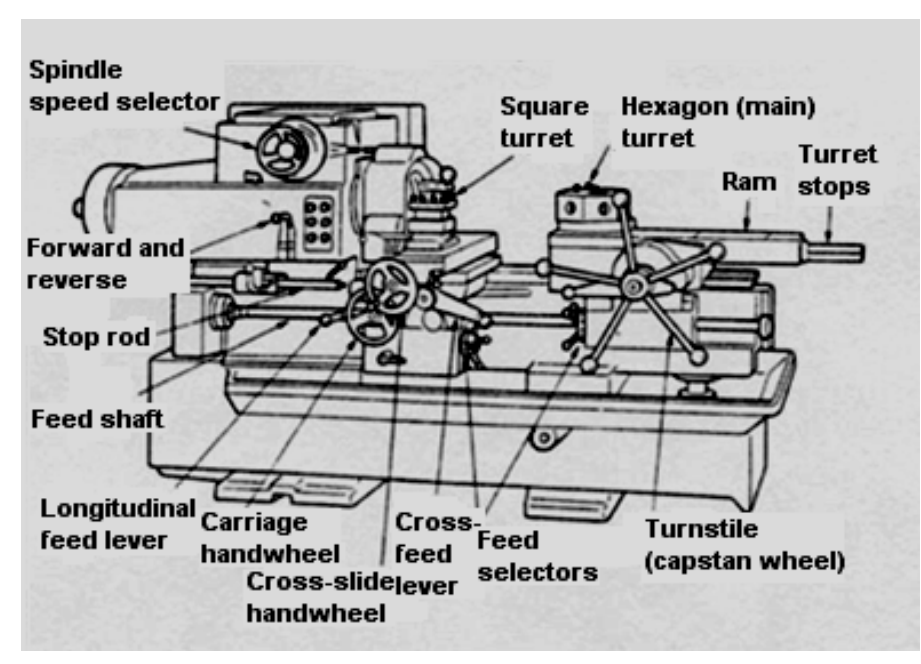

Figure 1. Parts of the Conventional.

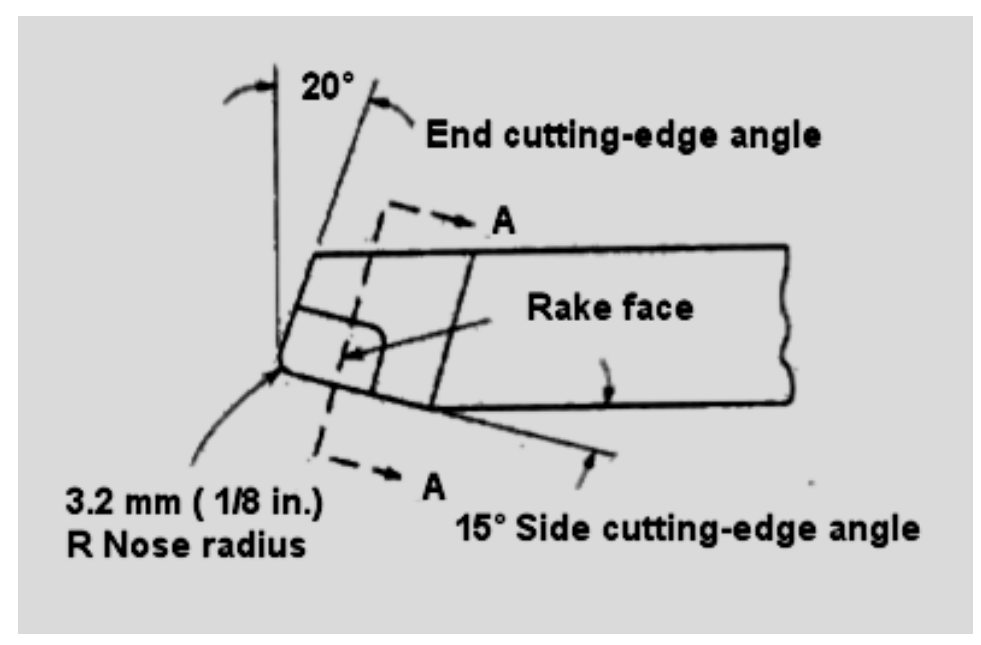

Figure 2. Parts of the Cutting Tool. 
In order to analyze the effect of the side cuttingedge angle on the surface roughness, an experimental Taguchi design was used.

\section{Methodology}

Given that aluminum is a material with good quality mechanics, very common also in the machine-tool industry, this experimental work was carried out on specimens of Aluminum 1350 using a conventional lathe; Table 2 describes the chemical composition of aluminum.

In order to analyze the effect of the side cuttingedge angle on the surface roughness, a Taguchi design L32 with two replicates was used. The control variables were spindle speed, feed rate, depth of cut and major side cutting-edge angle, while the surface roughness was the response variable. Table 3 shows the levels of the variables used in the experiment.

\begin{tabular}{|l|c|c|c|c|c|c|c|c|c|}
\hline Alloy & $\mathrm{Si}$ & $\mathrm{Fe}$ & $\mathrm{Cu}$ & $\mathrm{Mn}$ & $\mathrm{Mg}$ & $\mathrm{Cr}$ & $\mathrm{Zn}$ & $\mathrm{Ti}$ & $\mathrm{V}$ \\
\hline 1350 & 0.10 & 0.40 & 0.05 & 0.01 & - & 0.01 & 0.05 & $0.02+\mathrm{Ti}$ \\
\hline
\end{tabular}

Table 2. Chemical Composition of Aluminum 1350.

\begin{tabular}{|l|c|c|}
\hline Control Variables & Low & High \\
\hline Coding & 1 & 2 \\
\hline Spindle speed (rpm) & 625 & 950 \\
\hline Feed rate (in/min) & 1.6 & 3.0 \\
\hline Depth of cut (in) & .0156 & .1250 \\
\hline $\begin{array}{l}\text { Side cutting-edge angle } \\
\text { (degrees) }\end{array}$ & 0 & 5.0 \\
\hline
\end{tabular}

Table 3. Levels of the Variables Used in the Experiment. 
On the other hand, the results of the experimental run are given in Table 4:

\begin{tabular}{|c|c|c|c|c|}
\hline Spindle speed & Feed rate & Depth of cut & Side cutting-edge angle & Surface roughness ( $\mu$ in) \\
\hline 1 & 1 & 1 & 1 & 29.25 \\
\hline 1 & 1 & 1 & 1 & 22.75 \\
\hline 1 & 1 & 1 & 2 & 21.75 \\
\hline 1 & 1 & 1 & 2 & 30.75 \\
\hline 1 & 1 & 2 & 1 & 33.50 \\
\hline 1 & 1 & 2 & 1 & 28.75 \\
\hline 1 & 1 & 2 & 2 & 27.50 \\
\hline 1 & 1 & 2 & 2 & 33.25 \\
\hline 1 & 2 & 1 & 1 & 41.75 \\
\hline 1 & 2 & 1 & 1 & 34.50 \\
\hline 1 & 2 & 1 & 2 & 68.75 \\
\hline 1 & 2 & 1 & 2 & 48.25 \\
\hline 1 & 2 & 2 & 1 & 35.00 \\
\hline 1 & 2 & 2 & 1 & 37.25 \\
\hline 1 & 2 & 2 & 2 & 48.00 \\
\hline 1 & 2 & 2 & 2 & 52.75 \\
\hline 2 & 1 & 1 & 1 & 22.50 \\
\hline 2 & 1 & 1 & 1 & 24.50 \\
\hline 2 & 1 & 1 & 2 & 24.50 \\
\hline 2 & 1 & 1 & 2 & 29.00 \\
\hline 2 & 1 & 2 & 1 & 32.75 \\
\hline 2 & 1 & 2 & 1 & 35.75 \\
\hline 2 & 1 & 2 & 2 & 29.75 \\
\hline 2 & 1 & 2 & 2 & 33.25 \\
\hline 2 & 2 & 1 & 1 & 33.00 \\
\hline 2 & 2 & 1 & 1 & 29.50 \\
\hline 2 & 2 & 1 & 2 & 33.75 \\
\hline 2 & 2 & 1 & 2 & 46.00 \\
\hline 2 & 2 & 2 & 1 & 33.50 \\
\hline 2 & 2 & 2 & 1 & 34.00 \\
\hline 2 & 2 & 2 & 2 & 42.50 \\
\hline 2 & 2 & 2 & 2 & 42.75 \\
\hline
\end{tabular}

Table 4. Results of the Experimental Run 
In this way, 32 experiments were carried out with different combinations; each treatment was run randomly, the control variables were coded; thus, 2 indicated high level and 1 indicated low level. The surface roughness was measured using a stylus profilometer MITUTOYO model SURSTEST.301 and the arithmetic mean $R_{\mathrm{a}}$ was the measurement method used in the study; the reason for using this measurement method is its industrial usefulness.

\section{Data analysis}

Table 5 shows the analysis of variance for means. This analysis is used to determine the factors that significantly affect the surface roughness.
According to the data from ANOVA, with a confidence level equal to $90 \%$ and a $P<0.10$, the parameters and interactions that significantly affect the surface roughness are spindle speed, feed rate, side cutting-edge angle.

The interactions are spindle speed ${ }^{\star}$ feed rate, feed rate* side cutting-edge angle, feed rate*depth of cut and spindle speed*depth of cut.

Table 6 shows the analysis of variance for SN ratios.

\section{Analysis of Variance for Means}

Source

SPINDLE SPEED

FEED RATE

DEPTH OF CUT

SIDE OF CUTTING EDGE ANGLE

SPINDLE SPEED*FEED RATE

SPINDLE SPEED*DEPTH OF CUT

SPINDLE SPEED*

SIDE OF CUTTING EDGE ANGLE

FEED RATE*DEPTH OF CUT

FEED RATE*SIDE OF CUTTING EDGE ANGLE

DEPTH OF CUT*

SIDE OF CUTTING EDGE ANGLE

Residual Error

Total

\begin{tabular}{|c|c|c|c|c|c|}
\hline DF & Seq SS & Adj SS & Adj MS & $\mathrm{F}$ & P \\
\hline 1 & 69.62 & 69.62 & 69.618 & 10.23 & 0.024 \\
\hline 1 & 635.99 & 635.99 & 635.985 & 93.47 & 0.000 \\
\hline 1 & 24.69 & 24.69 & 24.688 & 3.63 & 0.115 \\
\hline 1 & 169.81 & 169.81 & 169.813 & 24.96 & 0.004 \\
\hline 1 & 89.66 & 89.66 & 89.657 & 13.18 & 0.015 \\
\hline 1 & 29.23 & 29.23 & 29.228 & 4.30 & 0.093 \\
\hline 1 & 16.25 & 16.25 & 16.251 & 2.39 & 0.183 \\
\hline 1 & 54.85 & 54.85 & 54.853 & 8.06 & 0.036 \\
\hline 1 & 169.81 & 169.81 & 169.813 & 24.96 & 0.004 \\
\hline 1 & 10.36 & 10.36 & 10.360 & 1.52 & 0.272 \\
\hline & $\begin{array}{r}34 \\
1304\end{array}$ & & .02 & 304 & \\
\hline
\end{tabular}

Table 5. Analysis of Variance for Means.
Source

SPINDLE SPEED

FEED RATE

DEPTH OF CUT

SIDE OF CUTTING EDGE ANGLE

SPINDLE SPEED*FEED RATE

SPINDLE SPEED*DEPTH OF CUT

SPINDLE SPEED*

SIDE OF CUTTING EDGE ANGLE

FEED RATE*DEPTH OF CUT FEED RATE*SIDE OF CUTTING EDGE ANGLE
DEPTH OF CUT*

SIDE OF CUTTING EDGE ANGLE

Residual Error

Total

\section{Analysis of Variance for SN ratios}

\begin{tabular}{rrrrrl} 
DF & Seq SS & \multicolumn{1}{l}{ Adj SS } & \multicolumn{1}{l}{ Adj MS } & \multicolumn{1}{c}{ F } & \multicolumn{1}{l}{ P } \\
1 & 3.0027 & 3.0027 & 3.0027 & 14.19 & 0.013 \\
1 & 37.2036 & 37.2036 & 37.2036 & 175.83 & 0.000 \\
1 & 2.7108 & 2.7108 & 2.7108 & 12.81 & 0.016 \\
1 & 7.9894 & 7.9894 & 7.9894 & 37.76 & 0.002 \\
1 & 3.4252 & 3.4252 & 3.4252 & 16.19 & 0.010 \\
1 & 1.5814 & 1.5814 & 1.5814 & 7.47 & 0.041 \\
1 & 0.2474 & 0.2474 & 0.2474 & 1.17 & 0.329 \\
1 & 4.1681 & 4.1681 & 4.1681 & 19.70 & 0.007 \\
1 & 6.9800 & 6.9800 & 6.9800 & 32.99 & 0.002 \\
1 & 0.6824 & 0.6824 & 0.6824 & 3.23 & 0.132 \\
& & & & & \\
31 & 1.0579 & 1.0579 & 0.2116 & &
\end{tabular}

Table 6. Analysis of Variance for SN ratios. 
The signal-noise $(\mathrm{S} / \mathrm{N})$ ratio is treated as a response of the experiment, which is a measure of the variation within a trial under noise factors and it contributes to reduce the variation within a trial. Therefore, in this experiment, the variables spindle speed, feed rate, depth of cut, side of cutting-edge angle and the interactions spindle speed ${ }^{\star}$ feed rate, spindle speed *depth of cut, feed rate*depth of cut and feed rate*side of cutting-edge angle are sources of variation. In addition, the machinist must carefully choose these cutting parameters or face an unacceptable finished surface.

Given that the purpose of this study is related to the effect of the side cutting-edge angle on the surface roughness, the following statistical analysis was done with respect to this cutting parameter. Figure 3 outlines the surface roughness behavior under two levels of side cutting-edge angles; therefore, Figure 3 indicates that there is a higher surface roughness when a workpiece is machined using a high side cutting-edge angle than when is machined with a low side cutting-edge angle. This behavior could be due to the vibration of the machine when it is used to high side cutting-edge angle during the turning process.

Figure 4 outlines the residual behavior of the data versus the side cutting- edge angle under two levels of side cutting-edge angles.

According to Figure 4, the variation of the residual values is most noteworthy at high side cutting-edge angles; therefore, under this machining condition, it is very probable that some machined parts will fall out of the specifications demanded by customers and, consequently, will be rejected. This is due to the wide variation caused by the high side cuttingedge angle. On the other hand, the interaction between feed rate*side cutting-edge angle significantly affects the surface roughness when the feed rate and the side cutting-edge angle are kept at high level. This is due to the vibration caused by the forces generated at high levels during the cutting process.

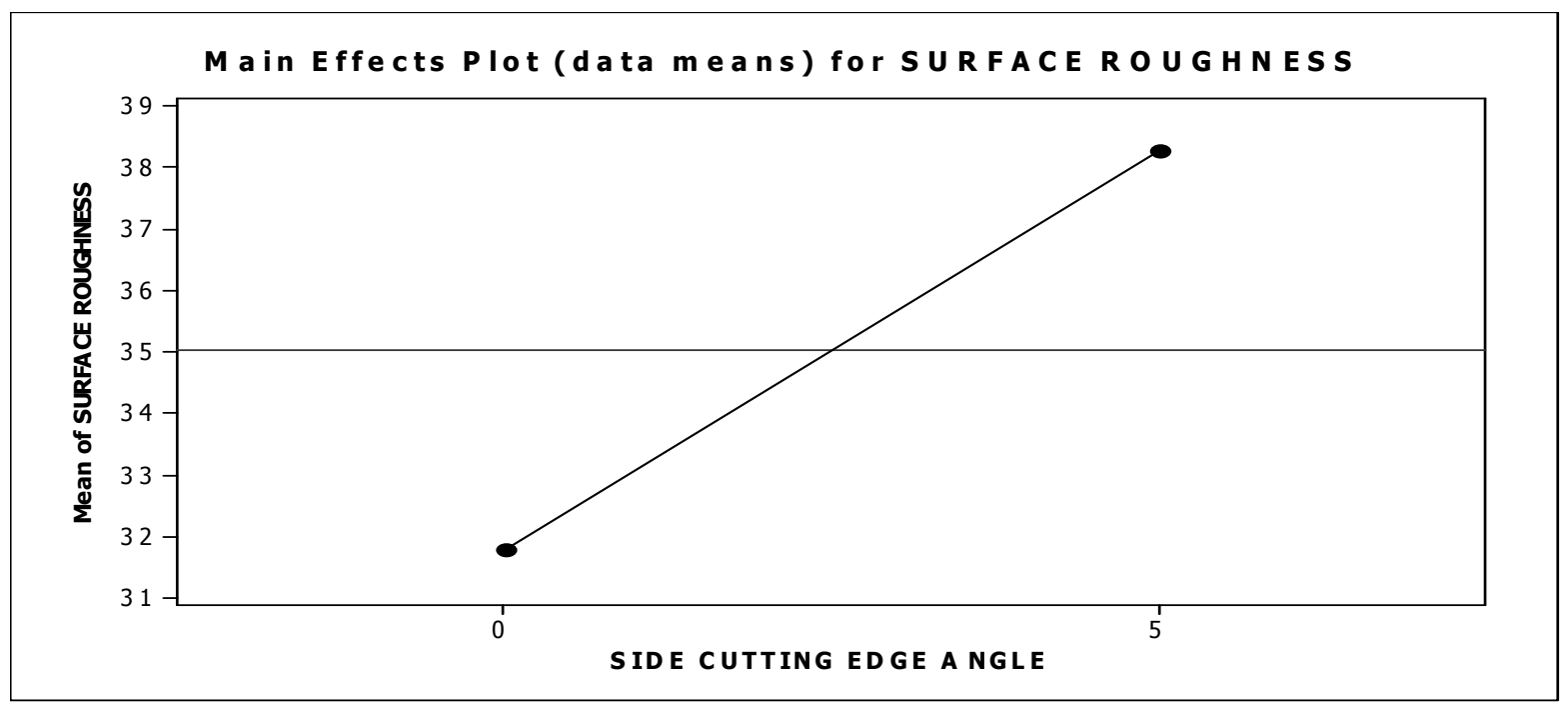

Figure 3. Side Cutting-Edge Angle Effect Plot for Surface Roughness. 


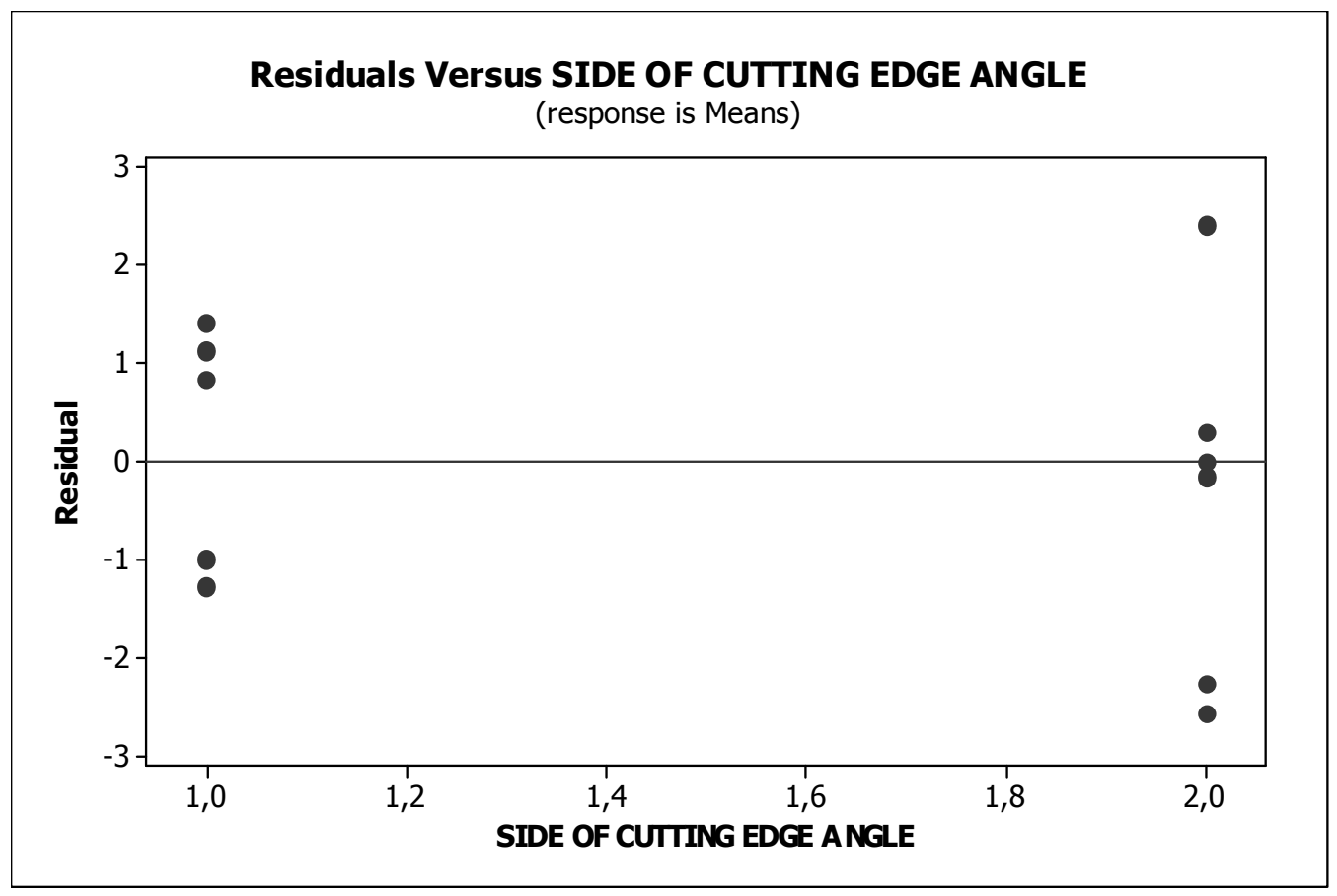

Figure 4. Residual vs Side Cutting-Edge Angle.

Figure 5 outlines the interaction plot of cutting parameters on the surface roughness.

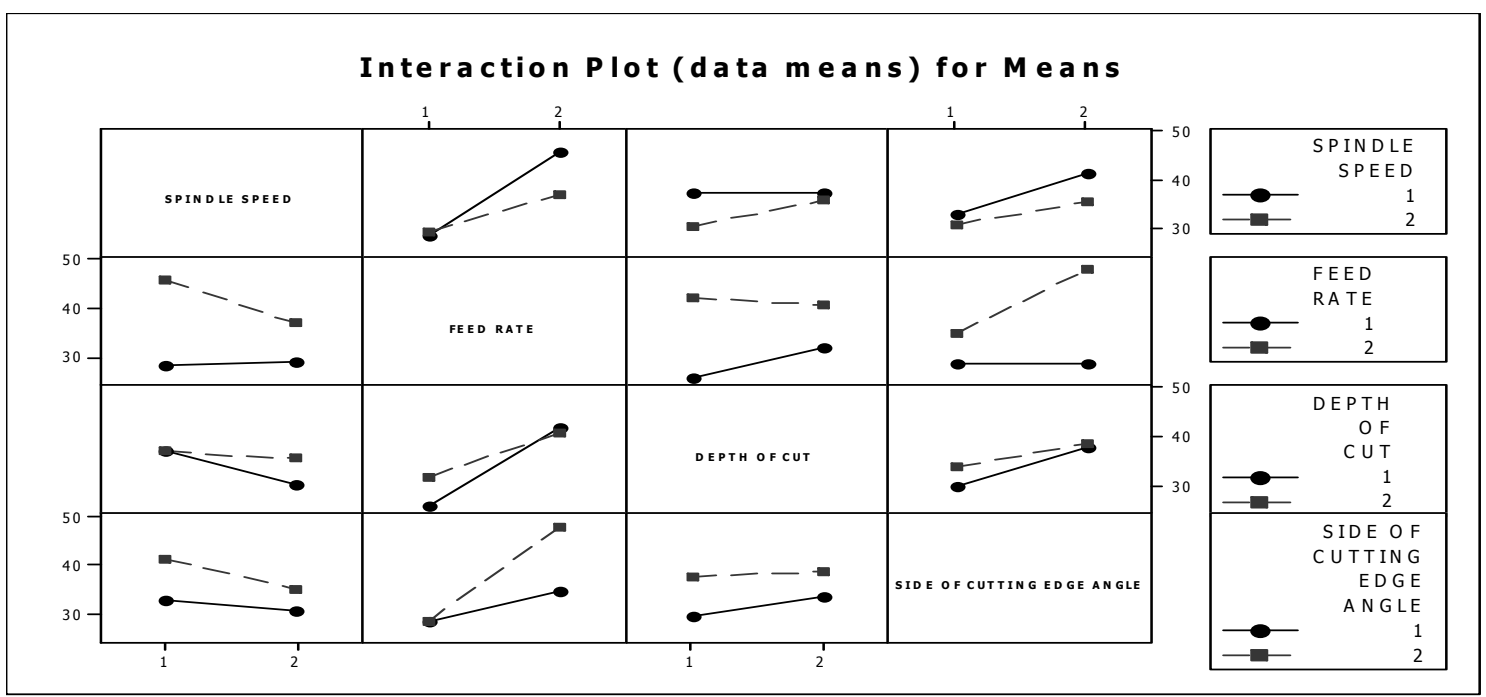

Figure 5. Interaction Plot for Surface Roughness. 
Finally, the surface roughness minimum is obtained by the gradient descendant method with the following combination of cutting parameters:

Spindle speed $=950 \mathrm{rpm}$, feed rate $=1.6 \mathrm{in} / \mathrm{min}$, depth of cut $=0.0156$ in, side cutting-edge angle $=0$ degree. This combination gives a surface roughness equal to $23.5 \mu \mathrm{in}$.

\section{Conclusions and recommendations}

- The side cutting-edge angle significantly affects the surface roughness; this could be due to the imperfect geometry of the cutting tool nose. Therefore, the surface roughness is affected when the cutting tool touches the workpiece at a different side cutting-edge angle. Also, the interaction feed rate*side cutting-edge angle also affects the surface roughness.

- There is a major residual variation when the workpiece is machined to high side cutting-edge angle; therefore, this condition can cause a wide variation regarding the specifications demanded by customers

- Others parameters that significantly affected the surface roughness were feed rate, spindle speed and interactions spindle speed ${ }^{\star}$ feed rate, spindle speed ${ }^{*}$ depth of cut and feed rate*depth of cut

- In further works, it will be important to analyze the effect of the side cutting-edge angle on the surface roughness for other work materials.

\section{References}

[1]. Feng, C.X. (Jack) and Wang, X., "Development of Empirical Models for Surface Roughness Prediction in Finish Turninig", International Journal of Advanced Manufacturing Technology Vol. 20, No. 5,Oct, 2002, pp.348-356

[2]. Nalbant, M., Gokkaya, H., and Toktaş, I. "Comparison of regression and Artificial Neural network Models for Surface Roughness Prediction with the cutting parameters", Vol. 2007, No 1, Jan, 2007, pp. 3-8

[3]. Zhang, J.Z. and Chen, J.C. "The development of inprocess surface roughness adaptive control system in end milling operations", International Journal of advanced Manufacturing Technology Vol. 31, Num 9-10, March, 2007, pp. 877-887

[4]. Mohamed A. Dabnun, M.S.J. Hashmi, M.A. ElBaradie Surface roughness prediction model by design of experiments for turning machinable glass-ceramic (Macor) Journal of Materials Processing Technology, Vol. 164-165, May, 2005, pp. 1289-1293

[5]. Ghani, J.A., Choudhury, Hassan, H.H. "Application of Taguchi method in the optimization of end milling parameters", Journal of Materials Processing Technology Vol.145, Num. 1, Jan. 2004, pp. 84-92

[6]. Puertas-Arbizu, C.J. and Pérez, L. "Surface roughness prediction by factorial design of experiments in turning processes". Journal of Materials Processing Technology. Vol. 143 - 144, Num. 20, Dec. 2003 pp. $390-396$

[7]. Bernardos, P.G., and Vosniakos, G.C. "Prediction of surface roughness in CNC FACE milling using neural networks and Taguchi's design of experiments", Robotics and Computer Integrated Manufacturing. Vol. 18, Num. 5-6, Oct-Dec. 2002, pp. 343-354

[8]. Darwish, S.M., "The impact of the tool material and the cutting parameters on surface roughness of supermet 718 nickel superalloy", Journal of Materials Processing Technology. Vol. 97, Num. 1-3, Jan, 2000, pp.10-18

[9]. Beauchamp Y., T.M., Youssef A.Y., Masounave J., "Effect of tool vibrations on surface roughness during lathe dry turning process", Computers Ind. Eng., Vol 31, No3/4, 1996, Dec, pp.637-644,

[10]. Alauddin, M., El Baradie, M.A., and Hashmi, M.S.J. "Prediction of tool life in end milling by Response Surface Methodology". Journal of Materials Processing Technology. Vol. 71, Num. 3, Nov. 1997, pp. $456-465$

[11]. Kalpakjian Serope \& Steven R.Schimid, Manufacturing Engineering and Technology, 4d Ed., Prentice Hall, 2001 


\section{Authors' Biographies}
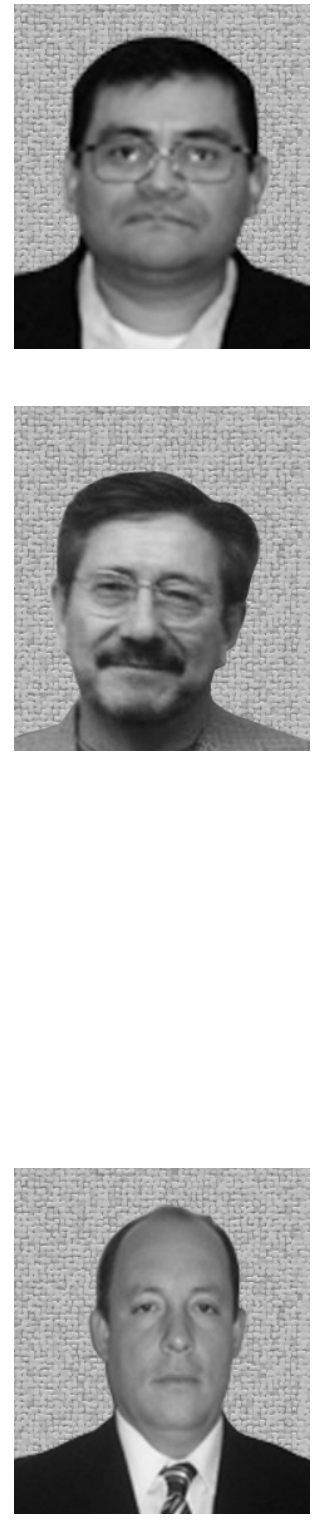

\section{Lazaro RICO-PEREZ}

Dr. Rico-Perez is professor of Manufacturing Engineering at Universidad Autónoma de Ciudad Juarez. Dr. Rico-Perez earned a master's degree in industrial engineering at Instituto Tecnológico de Orizaba and a doctorate degree in industrial engineering at Instituto Tecnológico de Ciudad Juárez. His research interests are manufacturing processes optimization and axiomatic design.

\section{Salvador NORIEGA-MORALES}

Dr. Noriega-Morales has a Doctor of Science degree in industrial engineering from Tecnológico de Ciudad Juárez. From 1998 to 2004, he was in manufacturing and quality consulting, certified by Nafin SNC, member of its web for business development. From 2003 to 2007, he was leader of the CA of Tech Planning and Ergonomic Design, now, Consolidated. Dr. Noriega-Morales has been member of the Society of Mexican Ergonomists -SEMAC-. PROMEP since 1997. He is also member of advisory committees of the International Society of Occupational Ergonomics and Safety, Accounting and Management (UNAM), and the International Journal of Industrial Engineering, in which he is invited editor for the special issues since 2007. He is a co-author of the books Ergonomía Ocupacional, Diseño y Administración del Trabajo and Manejo Manual de Materiales. He has authored more than 40 papers published in international journals and 60 papers in proceedings. At present, he teaches at the Doctor in Management Science Program of UNAM and is the Head of Industrial and Manufacturing Engineering at the Universidad Autónoma de Ciudad Juárez.

\section{Jorge Luis GARCIA-ALCARAZ}

Dr. Garcia-Alcaraz has a bachelor's degree in industrial engineering and a master's degree in science of industrial engineering from Instituto Tecnológico de Colima and a Ph.D. in science of industrial engineering from Instituto Tecnológico de Ciudad Juárez. His research interests are the multicriteria and multiattribute decision making and multivariate statistics applied to social and industrial problems. The result of his research has been published in the International Journal of Industrial Engineering -Theory, Applications and Practices-, Revista Contaduria y Administracion, Revista Agricultura Técnica en Mexico, among others. He has authored more than 50 papers published in international congresses and conferences and is a member of the National System of Researchers of CONACYT and Conacyt Accredited Assessors (RCEA).

He currently serves as professor at the Institute of Engineering and Technology at the Universidad Autónoma de Ciudad Juárez and teaches at the Master's and Doctoral programs. 

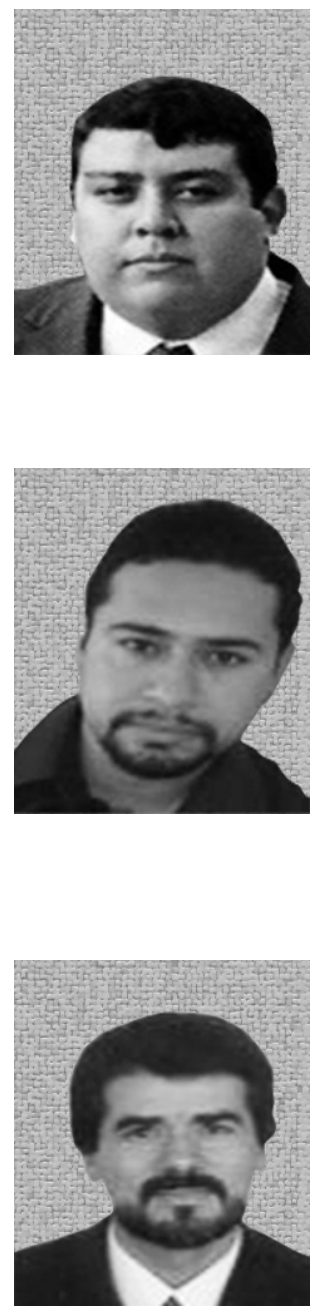

\section{Erwin Adan MARTINEZ-GOMEZ}

He is a professor at the Universidad Autónoma de Ciudad Juárez. He has a master's of science degree in industrial engineering from the Instituto Tecnológico de Orizaba, Veracruz. His areas of specialization include simulation of manufacturing systems, quality improvement and ergonomics. He has co-authored papers published in national and international journals.

\section{Raul Ñeco-Caberta}

He received a bachelor's degree in electromechanical engineering from Instituto Tecnológico de Tuxtepec, Oaxaca, Mexico in 1999 and a master's degree in mechatronic engineering from National Center for research and Technological Development, Cuernavaca, Mexico in 2003. He has been professor at the Universidad Autónoma de Ciudad Juárez since 2004. He is with the Department of Industrial Engineering and Manufacturing in the Institute of Engineering and Technology. His areas of interest are intelligent manufacturing, mechatronics systems, robotics and control.

\section{Francisco Javier Estrada-Orantes}

He is professor of Quality and Applied Statistics at Universidad Autónoma de Ciudad Juárez. He is also director of E-FACTOR GROUP, a consulting firm at El Paso, TX. Estrada-Orantes earned a master's degree in industrial engineering and a doctorate in engineering and environmental science from The University of Texas at El Paso. He is a senior member of ASQ and a senior member of IIE. 